\title{
PENTINGNYA ROTASI PARTISIPASI KOLABORATIF MANAJERIAL DEMI PENINGKATAN DAYA KOMPETITIF ORGANISASI DI PASAR GLOBAL
}

\author{
Lelo Yosep Laurentius \\ Character Building Development Center (CBDC), BINUS University \\ Jln. Kemanggisan Ilir III No. 45, Kemanggisan - Palmerah, Jakarta 11480 \\ lelojose@gmail.com
}

\begin{abstract}
The background of this research is based on the structure of a company as resource of structural stagnancy on its managerial level. Otherwise, the company structure has to face organizational multidimensional competition in global market. Stagnancy became a problem to an organization if there would be some consequences of working and synergy decreased significantly. The resolution of such stagnancy, especially to those agencies that had good and successful track record, like a manager, can be logically a job rotation. In this case, a manager as an asset of management resource plays an important and strategic position in order to develop a competitive organization in global market nowadays. This research mainly aims to modify the management resources as one of a business strategy to gain successfulness of a company sustainably. This study took quantitative, interpretative, and descriptive approach. The findings of this study indicated that a periodic change in such away like a rotation on the level of managerial collaborative participation which adjusted to the Theory of Contingency by Fiedler can be done in organization system. Besides, it can be held on the level of managers to adapt themselves throughout the global market competition.
\end{abstract}

Keywords: productivity, job rotation, management resources, leadership, global market

\begin{abstract}
ABSTRAK
Latar belakang kajian ini adalah struktur perusahaan sebagai sumber kejenuhan struktural pada manajer, padahal struktur perusahaan itu harus menghadapi multidimensi kompetisi organisasi di pasar global. Kejenuhan menjadi suatu masalah bagi organisasi jika mengakibatkan pekerjaan serta produktivitas menurun. Jawaban terhadap kejenuhan, khususnya bagi orang-orang yang punya riwayat keberhasilan seperti manajer, secara logis adalah rotasi pekerjaan. Manajer sebagai aset sumber daya manajemen memiliki posisi paling strategis bagi peningkatan daya kompetitif organisasi di pasar global. Kajian ini terutama bertujuan memodifikasi sumber daya manajemen sebagai strategi bisnis demi keberhasilan organisasi berkelanjutan. Penelitian ini menggunakan pendekatan kualitatif, bersifat interpretatif, dan deskriptif. Temuan kajian menunjukkan bahwa perubahan periodik berupa program rotasi partisipasi kolaboratif manajerial, sesuai teori Contingency Fiedler, dapat dilakukan dalam sistem organisasi. Sekaligus, program rotasi partisipasi kolaboratif manajerial tersebut dapat dilaksanakan pada para manajer sebgai penyesuaian diri terhadap lingkungan kompetitif di pasar global.
\end{abstract}

Kata kunci: produktivitas, rotasi pekerjaan, sumber daya manajemen, kepemimpinan, pasar global 


\section{PENDAHULUAN}

Meskipun ada perbedaan yang sangat jelas, Google, Microsoft, General Electric, dan Shell memiliki kesamaan perhatian yang mendalam bagi pengembangan sumber daya manajemen perusahaan. Itu bukan hal yang baru sebab Drucker (1973) telah menyatakan bahwa kita telah bergeser dari ekonomi barang ke ekonomi pengetahuan yang terdiri atas para pekerja profesional, manajerial, dan teknis. Semua CEO yang menghargai dirinya atau eksekutif senior lainnya mengakui fakta bahwa upaya pertumbuhan dan keberhasilan jangka panjang mengharuskan sejumlah manajer berkualitas dan berpengalaman untuk menjalankan organisasi. Kualitas dan dalamnya sumber daya manajemen kini lebih merupakan sumber keunggulan kompetitif daripada kapan pun di masa lalu.

Kajian ini mengulas bagaimana upaya intervensi organisasi untuk memodifikasi bakat manajer untuk manajemen yang unggul. Bakat manajer merupakan sumber daya manajemen yang strategis untuk berkompetisi di pasar global. Intervensi dilakukan dengan pendekatan teori Contingency (Fiedler, 1967) yang berbentuk program rotasi partisipasi kolaboratif manajerial. Intervensi ini dapat didesain pada tingkat sistem manajemen atau tingkat individu manajer. Program rotasi partisipatif kolaboratif manajerial bertitik tolak dari kenyataan bahwa struktur perusahaan merupakan kejenuhan yang tidak dapat dihindari. Kejenuhan struktural terjadi ketika seseorang tidak lagi dipromosikan untuk mencapai tanggung jawab-tanggung jawab yang dapat memberikan tantangan bagi ambisi dan eksitensinya di tempat kerja.

Ulasan dalam kajian ini lebih merekomendasikan agar intervensi terutama harus meliputi perubahan-perubahan di dalam sistem manajemen dengan dukungan sekunder yang ditujukan kepada pengembangan perilaku individu dalam organisasi. Rotasi pekerjaan manajerial merupakan salah satu solusi untuk mengatasi kejenuhan struktural itu dalam struktur organisasi perusahaan. Sebab, kejenuhan struktural menjadi masalah yang sangat berarti dalam semua organisasi yang berkembang sangat lambat. Kajian ini memberikan wawasan dan rencana bagaimana program rotasi partisipasi kolaboratif manajerial menjadi salah satu blueprint strategi bisnis organisasi demi berkompetisi di pasar global. Penguatan sistem pengembangan sumber daya manajemen yang strategis ini berbanding lurus dengan perkembangan daya kompetitif organisasi di pasar global. Hal ini terbukti pada korporasi multinasional seperti Google, Microsoft, General Electric, dan Shell.

Penelitian ini dipandu dengan dua pertanyaan strategis bagaimana organisasi dapat meningkatkan daya kompetitif di pasar global dengan memodifikasi sumber daya strategis internal. Pertama, apakah hubungannya pembahasan teori dan kajian rotasi partisipasi kolaboratif manajerial ini dengan praktek manajemen demi peningkatan daya kompetitif organisasi di pasar global. Dan kedua, mengapa organisasi mengabaikan pengembangan manajemen sebagai sumber untuk memecahkan masalah organisasional dalam keadaan sulitnya berkompetisi di pasar global.

\section{METODE}

Dilihat dari tujuannya, penelitian ini termasuk penelitian deskriptif. Penelitian deskriptif (descriptive research) merupakan penelitian yang dimaksudkan untuk mendeskripsikan secara sistematis tentang situasi, masalah, fenomena, program. Penelitian menyediakan informasi tentang sumber daya manajemen yang strategis dan sikap terhadap pemberdayaan sumber daya itu dalam kompetisi di level pasar global. Sedangkan data diperoleh dari kajian pustaka. 


\section{HASIL DAN PEMBAHASAN}

Betapa pentingnya penelitian Hawthorne dalam sejarah manajemen modern dan akhirnya juga bagi teori kepemimpinan saat ini. Bertempat di lokasi Hawthorne dari Western Electric Company di Chicago, penelitian selama sembilan tahun (1924-1932) memulai eksperimen canggih dalam tradisi manajemen ilmiah. Selama bertahun-tahun, dikumpulkan catatan tepat tentang produktivitas pekerja perakitan (merakit telepon) di bawah kondisi yang diubah secara saksama. Kondisi ini mencakup penerangan, suhu ruangan, penjadwalan waktu istirahat, dan sebagainya.

Agar dapat mengembangkan pilihan realistis terkait kombinasi kondisi kerja, para pekerja yang sedang diukur produktivitasnya sering dilibatkan dalam rapat perencanaan bersama manajer Western Electric serta kedua profesor dari Harvard (Elton Mayo dan F. J. Roethlisberger) yang mengepalai perencanaan dan pelaksanaan penelitian. Sering kali saran para pekerja, khususnya pekerja wanita yang bekerja dalam Relay Assembly Room, disambut baik dan dipadukan sebagai bagian dari rencana penelitian. Produktivitas meningkat tinggi selama tahap penelitian, tetapi satu hal yang membuat frustrasi manajer dan kedua profesor Harvard itu, yaitu tidak ada pertalian antara produktivitas dan berbagai kondisi fisik yang diterapkan.

Ketika kemudian diadakan wawancara penelitian (1928-1932), ketika para pekerja didesak untuk menyatakan sikap dan pendapat mereka soal hasil produktivitas yang tinggi, terungkaplah sebab dari peningkatan yang konsisten dalam produktivitas, yang mungkin tidak akan terjelaskan dengan cara lain. Selama penelitian berlangsung, pekerja sering dimintai saran dan gagasan mereka, sehingga merasa dirinya penting dan diakui sebagai orang yang masuk perhitungan. Insentif dan motivasi internal dari pekerja yang terlibat telah sangat berubah. Demikian juga sikap mereka terhadap pekerjaan serta keinginan untuk bobot pribadi dalam produktivitas lebih tinggi.

Rupanya tidak ada manajemen ilmiah yang bertanggung jawab terhadap tingginya produktivitas di Hawthorne. Hal itu lebih disebabkan variabel baru: sikap manusiawi, insentif, dan ikut merasakan pekerjaannya. Dalam pengertian teori perilaku di kemudian hari, kunci produktivitas Hawthorne adalah gaya dan iklim manajemen partisipatif. Hal ini sesuai dengan teori-teori dan hasil penelitian pendukung dari para pelopor ilmuwan perilaku Amerika seperti Rensis Likert dan Douglas MacGregor.

\section{Partisipasi dalam Organisasi}

Pertanyaan penting bagi organisasi adalah bagaimana cara mempertahankan atau menimbulkan kembali minat dan motivasi orang-orang yang tidak lagi begitu terlibat, kreatif, atau produktif dalam pekerjaan mereka seperti dahulu. Apa yang dapat dilakukan dengan atau bagi orangorang yang terganggu oleh kesenjangan antara persepsi awal mereka tentang potensi mereka dan perhatian organisasi yang sekarang menghilang terhadap mereka. Partisipasi adalah salah satu jawaban untuk memahami pertanyaan-pertanyaan eksistensi seseorang di tempat kerja. Sebab, pekerjaan menjadi fokus identitas dan memberikan banyak jawaban terhadap pertanyaan, "Siapakah saya?"

Partisipasi dapat didefinisikan sebagai tindakan melakukan sesuatu oleh, dengan dan lewat orang lain dengan menciptakan situasi keterlibatan mereka secara mental dan emosional dalam situasi yang mendorong adanya sumbangan yang positif kepada tujuan. Dalam definisi ini, kunci pemikirannya adalah keterlibatan mental dan emosional. Semua tindakan manajerial yang merangsang keterlibatan mental dan emosional orang lain memenuhi syarat definisi ini. Manajer berkomunikasi kepada pegawai lainnya tidak hanya apa yang perlu agar mereka dapat mengerjakan pekerjaanya dengan baik, tetapi juga jenis dan macam informasi yang mereka ingin tahu. Komunikasi itu berkontribusi memberikan perasaan yang lebih besar terkait identitas pegawai lainnya dengan unit kerja atau organisasi. Tindakan komunikasi manajerial tersebut menggunakan pedoman pendekatan partisipatif. 
Pedoman pendekatan partisipatif memposisikan manajer untuk beroperasi sesuai prinsip bahwa performa meningkat lebih spesifik jika sasarannya ditetapkan bersama. Partisipasi dalam penetapan sasaran organisasi akan meningkatkan performa selanjutnya. Manajer yang bekerja dengan memberitahu pegawai lainya tempat masing-masing dalam keseluruhan operasi sekaligus arti penting ekseistensinya dan pekerjaan itu berarti sesuatu bagi individu lainnya, akan mendapatkan manfaat dari keterlibatan mental dan emosional. Parisipasi pun tampak pada tindakan manajerial yang menyediakan umpan balik soal performa, penguatan positif, dan pendelegasian yang dikelola dengan profesional.

Meskipun para penganut manajemen ortodoks dapat membantah pandangan lebih luas dari partisipasi ini, kini cakrawala kompetisi di pasar global telah mendorong manajer dan organisasi untuk maju ke arah iklim yang lebih partisipatif. Tempat yang sesuai untuk mulai memodifikasi sumber daya manajemen adalah dengan mempelajari wewenang dan memikirkan bagaimana organisasi dapat menggunakannya secara positif untuk menimba potensi penuh dari sumber daya manusia organisasi (Thompson, Strickland, Gamble, 2007) demi berkompetisi di pasar global.

\section{Rotasi Kolaboratif Manajerial}

Struktur perusahaan merupakan kejenuhan yang tidak dapat dihindari. Kejenuhan struktural terjadi ketika seorang manajer tidak lagi dipromosikan di dalam organisasi. Hal ini mungkin merupakan masa depan yang membuat tertekan sebagian besar orang. Lalu, stagnasi tugas juga dapat mengecewakan karena tanggung jawab-tanggung jawab yang tidak berubah tidak memberikan tantangan bagi manajer. Sedangkan manajer memiliki posisi yang sangat strategis dalam usaha peningkatan daya kompetitif organisasi di pasar global. Rotasi pekerjaan merupakan salah satu solusi untuk mengatasi kejenuhan struktural dalam struktur perusahaan. Rotasi pekerjaan adalah perpindahan pekerja dari satu pekerjaan ke pekerjaan lain dalam satu unit kerja pada suatu organisasi perusahaan. Rotasi pekerjaan merupakan salah satu sistem pengembangan sumber daya manusia.

Kebijakan organisasi yang menyadari rotasi pekerjaan akan memudahkan timbulnya rasa kebersamaan. Pada perusahaan kecil seseorang terlibat dalam setiap pekerjaan orang lain. Sebaliknya, spesialisasi cenderung tidak disukai ketika ukuran organisasi perusahaan menjadi bertambah besar dan garis-garis batas antarfungsi muncul. Jika luput dari pemeriksaan, batas-batas ini dapat menjadi kaku dan tertutup rapat. Kebijakan perpindahan sementara para manajer pada tugas-tugas di luar batas-batas antarfungsi bertujuan mempertahankan suasana informal organisasi. Rotasi pekerjaan menjadi mekanisme integrasi organisasi namun hal ini mengandaikan adanya pekerjaan jangka panjang dan pelatihan yang intensif. Sebab, para manajer dan para spesialis di organisasi apapun lebih menyukai untuk mengembangkan hubungan kerja antarfungsi yang memuaskan, jika mereka mengetahui akan dimanfaatkan satu sama lain untuk kebaikan pekerjaan mereka (Iversen, 2000). Selain itu, kesetiaan dan komitmen mereka kepada perusahaan bertambah jika mereka mengetahui bahwa perusahaan secara berkesinambungan menyediakan kebijakan untuk meningkatkan keterampilan teknis mereka.

Perusahaan multinasional seperti Google, Microsoft, General Electric, dan Shell cenderung untuk memperlihatkan tanggung jawabnya terhadap hubungan jangka panjang dengan berbagai pihak. Mereka memandang dirinya sendiri sebagai bagian dari keabadian masyarakat yang di dalamnya termasuk para pegawai, pemegang saham, pemasok, dan masyarakat lokal. Tujuan mereka adalah mempertahankan kerja sama yang stabil dengan semua kelompok kepentingan.

Kerja sama ini merupakan tanggung jawab para manajer sebagai sumber daya manajemen strategis di organisasi perusahaan. Meskipun berbagai perusahaan multinasional ini mempunyai tujuan-tujuan bisnis yang yang jelas seperti pertumbuhan, keuntungan, dan saham pasar, mereka memandang hal-hal itu sebagai bagian dari tata nilai yang lebih tinggi, yaitu kejujuran, ketulusan, dan keterbukaan serta keutuhan antarfungsi organisasi secara keseluruhan. Nilai-nilai itu tak pernah dikorbankan demi tujuan jangka pendek. Perusahaan multinasional seperti itu tidak mengetahui janji apa yang tidak dapat mereka berikan kepada konsumen, pemegang saham, atau pegawai. 
Nilai-nilai perusahaan itu berdampak besar pada produk (Iversen, 2000). Misalnya, hampir tidak mungkin memperoleh produk yang rumit untuk diproduksi tanpa kepercayaan yang kuat antarfungsi, antara pegawai dan manajer, serta antara manajer dengan pemegang saham (pihak yang seharusnya melihat perusahaan melalui kemungkinan perkembangan penjualan dan pendapatan yang seringkali bersamaan dengan kemajuan teknologi). Di sisi lain, manajer berperforma unggul itu bukan terlahir, tetapi terlatih (Yukl, 2009). Kesimpulan ini merupakan hasil dari berbagai penelitian dalam bidang kinerja dan produktivitas di berbagai korporasi. Beberapa manajer secara naluriah memang memiliki ketrampilan spesifik dan perilaku kepemimpinan yang meningkatkan kinerja produktivitas dan efisiensi. Akan tetapi, ribuan lainnya menunjukkan perbaikan besar dalam tingkat performa setelah mereka mengambil langkah yang perlu untuk memperoleh ketrampilan itu. Manajer yang sukses memiliki ciri-ciri khusus yang memungkinkan mereka berperforma optimal (Zhivago, 2010). Kualitas itu dapat dipelajari.

Segala sesuatu yang menghambat aliran gagasan atau mengurangi kepercayaan, rasa hormat, dan rasa kebersamaan dalam mencapai tujuan bersama di antara individu merupakan bahaya yang potensial. Demi peningkatan daya kompetitif organisasi, maka energi dan kreativitas seluruh organisasi harus dipacu. Biasanya setiap kebijakan yang diambil untuk mengangkat salah satu dari fungsi tersebut di atas yang lain -apakah untuk gengsi atau penghargaan- dapat meracuni suasana kerja sama. Oleh karena itu, semua perusahaan multinasional sangat menentang perangkat organisasi yang lazim seperti senioritas, jabatan, dan spesialisasi fungsional. Demikian misalnya, antara rancangan produk, pemasaran, dan pengelolaan personal harus bekerja sama bukan saling bersaing sebagaimana terjadi pada banyak organisasi. Seseorang akan memahami ke mana perusahaan bergerak dan mengapa lebih mengesampingkan kepentingan dan unitnya sendiri atau fungsinya demi kepentingan atau tujuan-tujuan bersama. Jadi strategi bisnis memusatkan perhatian pada kepaduan sumber daya organisasi sebagai daya kompetitif utama di pasar global (Kaplan \& Norton, 2000).

Kepaduan sumber daya organisasi sangat tergantung pada peran strategis kepemimpinan manajer. Seorang manajer dapat saja dengan berbagai jalan menyumbang kepada efektifitas organisasi, tetapi tetap bukan seorang pemimpin yang efektif. Sebagai konsekuensinya, peran seleksi dalam memilih manajer yang efektif, yang berbeda dengan pemimpin efektif, masih berperan besar. Keberhasilan dalam kepemimpinan untuk menahkodai organisasi di pasar global bukanlah terbatas pada kalangan departemen tertentu saja, tetapi dapat dicapai oleh siapa saja dalam setiap departemen, dengan pengandaian bahwa situasinya tepat dan sang manajer dapat menyesuaikan perilakunya dengan situasi. Rotasi pekerjaan manajerial sebagai proses menuju kepemimpinan efektif pasti mengubah ciri individu, tetapi mengandaikan bahwa individu ditempatkan dalam situasi yang sesuai atau membimbing individu untuk berlaku sesuai dengan situasinya.

Program rotasi kerja kolaboratif manajerial sesungguhnya merupakan salah satu aplikasi teori Contingency (Fiedler, 1967) dalam semua situasi, semua variabel, gaya efektif pemimpin tergantung pada situasi tertentu itu sendiri; tidak ada satu pun gaya kepemimpinan tunggal yang efektif. Ivancevich, Konopaske, dan Matteson (2005) berpendapat bahwa efektivitas pemimpin dalam teori Contingency Fiedler ditentukan oleh interaksi antara faktor ciri individu (perilaku) dan faktor eksternal (lingkungan). Sedangkan pemimpin berkualitas, menurut mereka ditentukan oleh kemampuan untuk merancang pekerjaan agar sesuai dengan tipe kepemimpinan, yaitu task-oriented atau relationship oriented (Ivancevich, Konopaske, \& Matteson, 2005). Ringkasan Teori Contingency Fiedler terangkum pada gambar berikut. 


\section{Fiedler's Contingency Model: An Eight-Octant}

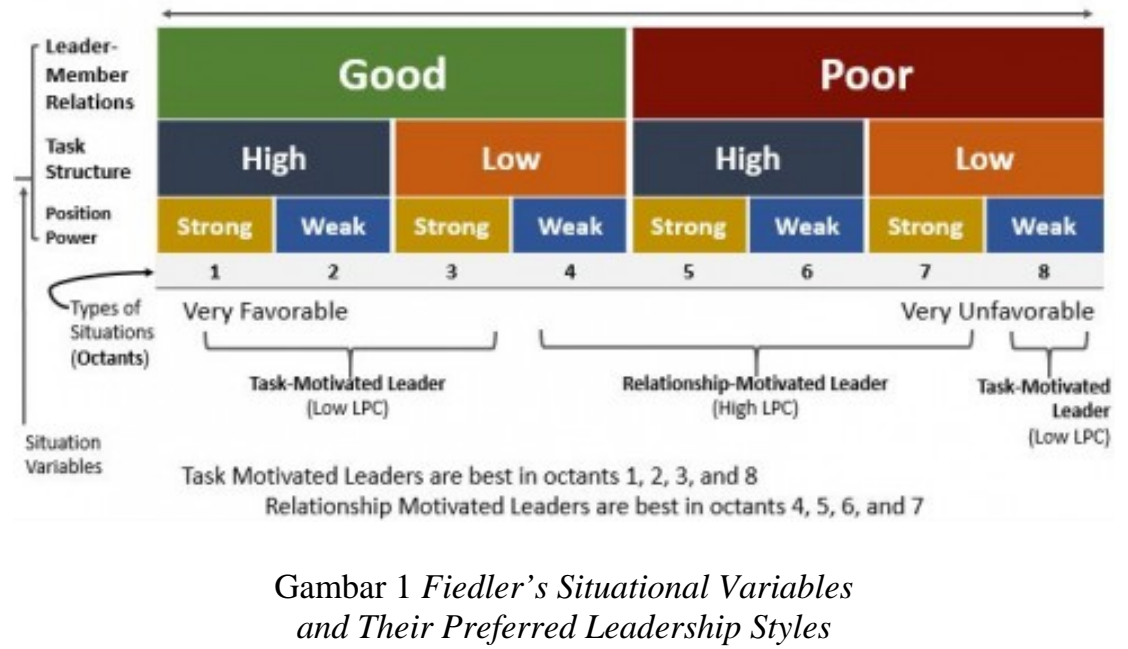

(Sumber: Matthews, 2013)

Kompleksitas situasi kompetisi di pasar global merupakan faktor eksternal (lingkungan) yang berpengaruh besar pada kondisi eksistensi organisasi. Organisasi merespons kompleksitas itu dengan modifikasi perilaku dan gaya pimpinan pada tiga aspek situasi internal, yaitu relasi pimpinanbawahan, struktur tugas, dan kekuasaan posisi. Berbagai pengalaman nyata para pimpinan di berbagai organisasi multinasional dewasa ini menyatakan bahwa setiap situasi yang mereka tangani menuntut gaya kepemimpinan yang berbeda. Tidak satu pun gaya tunggal cukup untuk menangani variasi kondisi sehari-hari yang sangat dinamis, bahkan berbeda dari menit ke menit, menghadapi kepribadian dan keadaan jiwa yang berbeda dari pegawai. Ditambah lagi, variasi dalam proses rutin versus tantangan atau jadwal waktu mendesak, birokrasi dan peraturan pemerintah yang baru atau selalu berubah, peran ganda dari pekerja, kisaran luas dalam kerumitan pekerjaan mulai dari yang sederhana sampai yang menuntut inovasi, dan sebagainya.

Teori Contingency (teori manajemen menurut keadaan) menuntut manajer yang efektif harus memiliki banyak gaya kepemimpinan dan tahu memanfaatkan gaya yang paling sesuai untuk situasi tertentu. Efektivitas manajerial yang sesuai kompleksitas kompetisi di pasar global dapat ditingkatkan lewat pengembangan keterampilan teknis melalui program rotasi kerja kolaboratif manajerial. Rotasi ini bertujuan untuk menganalisis sifat dari situasi organisasi - baik tuntutan tugas maupun politis secara keseluruhan dalam organisasi. Agar manajer dapat menjadi pemimpin yang efektif, mereka harus berusaha untuk menjadi cerdik secara politis dan membentuk perilaku mereka, dengan memperhitungkan perbedaan dalam situasi, bawahan dan atasan. Tentu saja proses pembelajaran ini membutuhkan waktu. Jadi teori Contingency Fiedler sesungguhnya menerima realitas yang tidak nyaman terkait kepemimpinan yang begitu rumit dan tergantung dari banyak variabel situasionalnya.

Salah satu realitas dinamika manajerial adalah manajer tergantung dari teman sejawat, atasan dan bawahan untuk menyelesaikan tujuan terkait dengan pekerjaannya. Ini adalah bidang-bidang pekerjaan yang mudah terserang, yaitu kurangnya kerja sama dengan orang lain dapat meniadakan pencapaian produktivitas dan efisiensi. Ketergantungan manajerial, apakah berbentuk kebutuhan kerja sama antardepertemen, informasi yang dimiliki orang lain dan tidak dimiliki manajer, atau berbagai bentuk dukungan yang perlu, berakhir dalam situasi di mana manajer harus mampu mempengaruhi dengan positif mereka pada siapa manajer tersebut bergantung (Iversen, 2000).

Ketergantungan cenderung meningkat pada tingkat lebih tinggi dari hirarki organisasi, demikian juga dengan jumlah orang yang melapor baik langsung maupun tidak langsung pada manajer. Ketergantungan juga sangat bervariasi sebagai fungsi dari besarnya organisasi, lingkungan, 
sasaran, teknologi, susunan resmi dan sistem imbalan. Semakin besar jumlah dan luasnya ketergantungan, semakin banyak pula waktu dan energi managerial harus dimasukkan dalam perilaku yang berorientasikan pada wewenang dan kekuasaan, untuk lebih memudahkan daripada menghalangi tercapainya tujuan produktivitas dan efisiensi organisasi (Robbins, 2003).

Jadi rotasi kerja kolaboratif manajerial adalah salah satu bentuk program pengembangan sumber daya manajemen yang strategis di organisasi perusahaan berdasarkan pada teori Contingency. Sama dengan adanya tahapan dalam pertumbuhan orang dewasa, demikian juga dengan manajer. Makin banyak saja organisasi perusahaan yang mengakui dan menyediakan kesempatan demi mempelajari tahapan pengembangan itu dalam konteks perencanaan strategis organisasi terkait program latihan sumber daya manajemen khusus. Jika hal ini terjadi, pegawai, pemegang saham, pemasok, dan masyarakat lokal serta para pihak berkepentingan akan dikelola dengan lebih baik, sehingga kinerja produktivitas dan efisiensi akan meningkat secara konsisten.

\section{Kompetisi Pasar Global sebagai Sebuah Masalah Kompleks}

Ada beberapa alasan fakta sengitnya persaingan di pasar global. Pertama, fakta menyempitnya kesenjangan teknologi. Kedua, makin banyak perusahaan pesaing dikelola dengan sangat baik, sehingga kesenjangan manajemen pun dapat menjadi lebih sempit. Bahkan sudah menjadi kenyataan umum, bahwa banyak dari perusahaan baru dalam industri teknologi informasi dimulai oleh wiraswastawan muda yang berasal dari perusahaan raksasa, yang mereka sulit dapat mengembangkan semangat dan keterampilan wiraswastawan mereka. Ketiga, tingkat pendidikan rata-rata sumber daya manajemen meningkat dan gelar MBA pun sekarang sudah menjadi sangat umum di semua organisasi.

Ada tiga sudut pandang cara memahami kemampuan perusahaan bersaing di pasar global dan memasuki pasar asing (Djohanputro, 2008). Pertama, didasarkan atas teori keunggulan komparatif (comparative advantage). Penganut teori ini mendasarkan argumennya berdasarkan keunggulan komparatif suatu negara dan prinsip spesialisasi. Kemampuan memproduksi barang dan jasa dengan murah karena adanya kekayaan (endowment) yang telah tersedia di negara tersebut, misalnya sumber daya alam, tenaga kerja yang murah, dan kebijakan pemerintah yang transparan dan sebagainya. Bisa juga murahnya ongkos produksi disebabkan oleh tersedianya bahan masukan hasil ciptaan, misalnya teknologi yang maju, akumulasi modal, kekayaan informasi, dan sebagainya. Kemampuan menggunakan kekayaan tersebut dengan baik meningkatkan daya saing secara komparatif dibandingkan negara lain. Spesialisasi menyebabkan terjadi overproduction untuk barang dan jasa tertentu dan underproduction untuk barang dan jasa lainnya. Konsep keunggulan komparatif membantu untuk mengevaluasi dan memahami pengembangan usaha ekspor-impor.

Kedua, dibangun atas konsep ketidaksempurnaan pasar (imperfect market concept), yang menyatakan bahwa oleh karena pasar tidak sempurna maka harga-harga bahan baku dan masukan industri berbeda-beda di lokasi yang berbeda. Konsep ini membantu kita memahami mengapa suatu perusahaan asing melakukan ekspansi bisnis di negara lain. Ketiga, sudut pandang siklus hidup produk, yang mampu menjelaskan mengapa suatu perusahaan mampu melakukan ekspor, mendirikan cabang, sampai mendirikan anak perusahaan di negara lain. Konsep ini sering diaplikasikan untuk produk-produk teknologi tinggi atau memiliki tingkat keunikan yang tinggi. Pemasaran suatu produk dimulai dari pasar domestik. Setelah muncul permintaan dari negara lain, tetapi pada skala yang relatif kecil, mulai dengan ekspor. Pada saat permintaan meningkat, diperlukan pengawasan yang lebih baik dan perwakilan di pasar lokal untuk penyelesaian transaksi dan administrasi; berdiri kantor cabang di pasar lokal. Pada saat permintaan terus meningkat dan melewati batas minimum (critical mass), diperlukan pendirian anak perusahaan (subsidiary) di pasar lokal. Pendirian anak perusahaan tersebut bisa melalui akuisisi perusahaan domestik yang sudah ada, bisa juga dengan cara pendirian perusahaan dari awal. 


\section{Implikasi Organisasional}

Rupanya seleksi tidak merupakan jawaban yang tepat atas kebutuhan organisasi untuk menambah perbendaharaan pemimpin yang efektif. Jantung dari manajemen efektif adalah kepemimpinan efektif (Higgs, 2003). Namun demikian dalam sebagian besar organisasi persentase besar dari promosi manajerial dibuat dengan cara serampangan. Memang menjadi fakta nyata bahwa banyak manajer lini pertama pada mulanya dipilih dengan cara subjektif dan pada akhirnya (entah lewat senioritas, kesempatan, penipisan tenaga kerja, atau tidak adanya alternatif lain), menggeser kedudukan manajerial puncak ketika keterampilan kepemimpinan memainkan peran yang sangat penting dan strategis dalam penentuan pertumbuhan vertikal dan kemakmuran organisasi.

Para manajer baru yang belum mengembangkan kualitas mereka sendiri untuk kepemimpinan efektif kurang memiliki peluang wajar untuk mencapai keberhasilan konsisten jika mereka dihadapkan pada masalah situasional manajemen sehari-hari. Mereka akan mempunyai kemungkinan keberhasilan manajerial lebih besar jika mereka membawa serta ke dalam kedudukan mereka beberapa ciri kepemimpinan terlahir. Keberhasilan organisasional juga meningkat nyata jika proses pemilihan pada tingkat manajerial didasarkan pada konsep jelas tentang bagaimana penampilan dan perilaku pemimpin itu (Chun, 2013).

Organisasi yang memiliki pengertian jelas tentang sifaf kelompok akan memperlihatkan keterkaitan konsisten dengan fungsi kepemimpinannya (Stoner \& Winkel, 2003). Organisasi seperti ini akan lebih mudah dan efektif untuk menilai individu yang memiliki kuosien kepemimpinan tinggi. Kebijakan organisasi akan mempromosikan kemampuan itu dan tidak mengekangnya. Dalam proses promosi itu sering kali reaksi naluriah ikut berperan. Hal ini sangat baik dan seharusnya begitu. Namun seorang mungkin tidak mendapatkan bimbingan dari sanubari. Jika dihadapkan pada pilihan antara beberapa orang yang berkualifikasi untuk kedudukan manajerial, acapkali seorang memilih yang paling senior atau orang yang secara teknis paling berkompeten dalam bidang spesifiknya, dan bukan individu dengan kualitas kepemimpinan. Yang pernah membuat dan merasakan akibat dari pilihan yang tidak benar seperti itu, menyadari risiko mempromosikan seseorang sesuai dengan faktor tujuan tetapi sering tidak relevan. Beberapa situasi tertentu agaknya mendorong timbulnya sifat kepribadian atau kemampuan yang mirip dengan kepemimpinan, sehingga memperkenankan individu untuk memecahkan masalah bagi orang lain sebagai pertumbuhan dari waktu atau tempat tertentu.

Kemampuan organisasi untuk mengembangkan kesadaran manusiawi dan kesadaran diri setiap manajer, sebagian besar akan menentukan kualitas kehidupan kerja dalam tempat kerja (Luthans, 1988). Orang cepat menanggapi pemimpin yang dapat memantapkan iklim kepercayaan mendasar, saling menghormati dan mendukung. Namun mereka pun dengan cepat menentang arahan dari manajer jika mereka tidak memiliki hubungan batin.

Belum banyak organisasi yang memercayai hal itu. Program pengembangan kepemimpinan manajerial dalam organisasi seperti itu mungkin tidak ada atau paling baik hanya ala kadarnya saja. Penekanan pada segi perilaku dalam program pengembangan kepemimpinan adalah suatu keharusan jika strategi pengembangan sumber daya manusia hendak mencapai tingkatan tertinggi dalam jajaran organisasional (Iversen, 2000).

Dalam pengertian pengembangan kepemimpinan, sangat tidak mencukupi untuk mengirim seorang manajer mengikuti seminar sehari mengenai kepemimpinan. Jenis kegiatan seperti itu begitu menonjol dalam program pengembangan organisasional sekarang ini, yang menggambarkan betapa dangkalnya pengertian tentang pertumbuhan atau perkembangan manusia itu sendiri. Memilih manajer dengan kuosien kepemimpinan tinggi hanya merupakan bagian dari tugas organisasional (Robbins, 2003). Mempersiapkan manajer agar dapat berfungsi antarpribadi dengan efektif adalah kunci tambahan dalam setiap proses pemilihan. Hal ini mencakup sifat dan ketrampilan apa yang harus 
diperkuat, kemudian merencanakan program yang dapat menumbuhkan pengertian yang dalam tentang sifat multidimensi manusia dalam organisasi.

\section{SIMPULAN}

Partisipasi pada rotasi kolaboratif manajerial merupakan upaya penetapan sasaran dan strategi organisasi untuk meningkatkan performa daya kompetitif organisasi demi mengantisipasi pasar global sesuai teori-teori dan hasil penelitian pendukung dari para pelopor ilmuwan perilaku Amerika Rensis Likert dan Douglas MacGregor. Sebab, manajer yang bekerja dengan memberitahu pegawai tempat mereka dalam keseluruhan operasi, akan mendapatkan manfaat dari keterlibatan mental dan emosional para pegawainya, sehingga kualitas kerja di tempat kerja semakin kondusif untuk produktif. Sedangkan perilaku kepemimpinan manajer berperforma unggul itu bervariasi dan tergantung dari (a) kepribadian individual manajer sendiri, (b) pengikut individual, jenis orangnya dan jenis pekerjaan yang mereka lakukan, dan (c) situasi tertentu dan keadaan pada saat sedang berlaku.

Rotasi kolaboratif manajerial merupakan salah satu bentuk penerimaan realitas yang tidak nyaman mengenai kepemimpinan manajerial yang begitu rumit dan tergantung dari banyak variabel situasional seperti pasar global saat ini. Selain itu, rotasi kerja manajerial merupakan salah jawaban yang tepat atas kebutuhan organisasi untuk menambah perbendaharaan pemimpin yang efektif. Dewasa ini, seleksi tidak memadai untuk menciptakan pemimpin yang efektif untuk meningkatkan daya kompetitif organisasi di pasar global yang kompleks.

Jantung dari manajemen efektif adalah kepemimpinan efektif. Keterampilan kepemimpinan berperan vital dan strategis dalam penentuan pertumbuhan vertikal dan kemakmuran organisasi dari waktu ke waktu. Demi mengantisipasi perubahan arah pilihan daya kompetitif organisasi di pasar global, sumber daya manajemen memerlukan kegesitan dan keberanian untuk menerima intervensi strategi organisasi. Kegesitan organisasi tampaknya berhubungan dengan keluwesan organisasional. Penyusunan kembali personil dan tanggung jawab sumber daya manajemen merupakan strategi untuk mempertahankan keseimbangan dalam kompleksitas perubahan persaingan. Jadi dalam perjuangan untuk memperbaiki kinerja produktivitas dan efisiensi organisasi dan keuntungan-keuntungan yang akan dihasilkan, teknologi dan modal adalah senjata yang penting. Akan tetapi, hanya manusia yang dapat menentukan siapa yang menjadi pemenangnya.

\section{DAFTAR PUSTAKA}

Chun, J. (2013). Top 10 Management Practices of Effective Leaders. Diakses 30 Agustus 2013 dari http://www.careerfaqs.com.au/news/news-and-views/top-10-management-practices-ofeffective-leaders/.

Djohanputro, B. (2008). Memahami Persaingan Global. Diakses 27 Agustus 2013 dari http://bram39.files.wordpress.com/2008/09/memahami-persaingan-global-30-08-08.pdf .

Drucker, P.F. (1973). Management : Tasks, Responsibilities, Practices. New York : Harper \& Row

Fiedler, F.D. (1967). A Theory of Leadership Effectiveness. McGraw-Hill

Higgs, M. (2003). How can we make sense of leadership in the 21st century? Leadership and Organizational Journal, 24, 273-284. 
Ivancevich, J. M., Konopaske, R., Matteson, M. T. (2005). Organizational Behavior and Management. Boston: McGraw Hill.

Iversen, O. I. (2000, May). Managing people towards a multicultural workforce: an investigation into the iimportance of managerial competencies accross national borders in Europe - differences and similiarties. Presented at the 8th World Congress on Human Resource Management. Paris.

Kaplan, R. \& Norton, P. (2000). The Strategy-focused Organization. Boston: Harvard Business School.

Luthans, F. (1988). Successful vs Effective Real Managers. Diakses 30 Agustus 2013 dari http://www.be.wvu.edu/divmim/mgmt/blakely/homepage/BADM543Leadership/Summer07/ Readings/LeadingvsManaging.htm.

Matthews, J. (2013, 12 November). Leadership Theories: Three Types of Contingency and Situational Theories. Diakses 14 Juli 2014 dari http://jasonmatthews.hubpages.com/hub/LeadershipTheories-Three-Types-of-Contingency-and-Situational-Theories [diakses]

Mayo, E. (1945). Social Problems of an Industrial Civilization.

Robbins, S. (2003). Organizational Behaviour. New Jersey: Prentice Hall.

Roethlisberger, F.J. (1939). Management and the Worker. Harvard Press.

Stoner, J. A. F. \& Winkel C. (2003). Perencanaan dan Pengambilan Keputusan dalam Manajemen. Alih bahasa: Simamora Sahat. Jakarta: Rineka Cipta.

Thompson, Jr. A. A., Strickland III, A. J., Gamble, J. E. (2007). Crafting and Executing Strategy: the Quest for Competitive Advantage Concepts and Cases. New York: Mc Graw-Hill.

Yukl, G. (2009). Kepemimpinan dalam Organisasi. Alih bahasa Budi Supriyanto. Jakarta: INDEKS.

Zhivago, K. (2010, 24 Jan). Top 10 Characteristics of An Effective Leader. Diakses 28 Agustus 2013 dari http://www.revenuejournal.com/2010/01/top_10_characteristics_of_an_e.php. 